\title{
CHANGES IN CZECH FAMILY LAW IN LIGHT OF THE PRINCIPLES OF EUROPEAN FAMILY LAW
}

\section{Zdeňka KRÁLÍČKOVÁ ${ }^{1}$}

Czech family law has recently been re-codified as part of the new Civil Code. The intention of its main drafters was to build on the values and traditions of Christian-Jewish culture in the Czech Republic and to enrich Czech family law with a new dimension, especially in relation to international human rights conventions and developments in the field of human rights in general. Some sections have also been significantly influenced by the Principles of European Family Law (PEFL) developed by the Commission on European Family Law (CEFL) aiming at 'better law' and the harmonization of family law systems in Europe. It was stressed that the Principles of European Family Law regarding Divorce and Maintenance Between Former Spouses, the Principles of European Family Law regarding Parental Responsibilities and the Principles of European Family Law regarding Property Relations Between Spouses were published during the time of recodification of the new Civil Code and took into consideration. However, the Principles of European Family Law regarding the Property, Maintenance and Succession Rights and Duties of Couples in de facto Unions were published later. It is unclear whether the concept of unmarried cohabitation will be a challenge for Czech legislators. One can agree with the view that the new private law code should, in principle, cover all private law matters, including family law, as is customary in countries with comparable legal environments. And finally, the article was focused on the pending drafts, as developments in this area are not over, as further changes are on the way.

\begin{tabular}{l|l} 
family law \\
the Czech Republic \\
Czech family law \\
principles \\
European family law
\end{tabular}

1 | Professor, Faculty of Law, Masaryk University in Brno, the Czech Republic, zdenka.kralickova@ law.muni.cz. 


\section{Introduction}

The twentieth century is often referred to as the century of human rights conventions, constitutions or charters of fundamental rights, and freedoms. There is no doubt that family law has gradually been influenced by international conventions, the case law of the European Court of Human Rights, and new approaches to family law by constitutional courts, not only in the Czech Republic, but also in Europe and the world in general. ${ }^{2}$ One can also say that it has been given a new dimension by the Principles of European Family Law (hereinafter PEFL or Principles I, II, III, IV) drawn up by the Commission on European Family Law (CEFL), ${ }^{3}$ even though they are not binding. Many changes are taking place despite the fact that family law is said to be the least suited to harmonization or unification. The reasons given include tradition, culture, religion, political climate, ideology, and conservatism ${ }^{4}$-terms that reflect a certain kind of inertia. Several other questions are raised here, ${ }^{5}$ particularly regarding whether further harmonization or unification of family law in Europe is merely utopic thinking or a realistic goal. ${ }^{6}$ It is generally acknowledged that family law in Europe is diverse, having been influenced by the legal arrangements enshrined in the great civil codes such as those of France, Germany, or Austria, as well as former Soviet law.?

An extensive range of opinions ${ }^{8}$ have been published regarding the harmonization or unification of family law in Europe, representing a certain degree of dynamism ${ }^{9}$ in addition to the above-mentioned inertia, stagnation, or rigidity. These are not primarily political issues..$^{10}$ Following the establishment of the European Union and the gradual formation of European private law, many new approaches have been required, particularly in relation to the free movement of persons who marry, enter into partnerships, or live together informally, and have children together, whether naturally or through assisted reproduction or adoption, foster care, or other forms of substitute family care of minor children. ${ }^{11}$

Although Czech family law has been significantly changed recently as part of the recodification of the basic source of private law-the Civil Code, ${ }^{12}$ into the core of which it has been reintegrated ${ }^{13}$-its form is not final and new questions are being asked. Many amendments are being debated in the Parliament of the Czech Republic. Some of the proposed changes are conceptual, such as the proposal to enshrine 'marriage for everyone', 14 while others proposals are partial but not insignificant. ${ }^{15}$

2 | See Králíčková, 2010.

3 | For details see http://ceflonline.net/.

4 | Towards development of family law in Europe see Douglas, Lowe, 2009.

5 | For more see Meulders-Klein, 2003, p. $111-112$.

6 | See Martiny, 1995, p. 419 ff.; Martiny, 1998, p. 151 ff.

7 | For details see Mladenović, Janjić-Komar, Jessel-Holst, 1998.

8| Towards different views see Antokolskaia, 2003, pp. 28-49.

9 | See Pintens, 2003, p. 20 ff.

10 | See Brüggemeier, Colombi Ciacchi, Comandé, 2010, and Brems, 2008.

11 | See Králíčková, 2012.

12 | See Act No 89/2012 Sb., Civil Code, as amended. It came into effect on the 1st January 2014.

13 | For details see Králíčková, 2013, p. 801 ff.

14 | Parliament of the Czech Republic, Chamber of Deputies, Parliamentary term No. VIII., Draft No. 211/0.

15 | For details see Králíčková, 2021. 


\section{On the Principles of European Family Law}

If we admit that there has been a certain convergence of family law in Europe, or Europeanization, we can further ask whether this is a controlled process or a spontaneous convergence due to respect for the universally recognized and shared values on which the Christian-Jewish culture in Europe is based. These include respect for human beings, their private and family life, or life in general, human dignity, freedom, honor, equality, autonomy of the will, solidarity, and the protection of the weaker party, whoever it may be. Traditionally, the minor child has been considered the weaker party due to age. However, the weaker party can be anyone, which is especially relevant in legislation on matrimonial property law and family home.

Many experts on family law share an optimistic vision of a gradual value enrichment of systems offamily law ${ }^{16}$ and their positive evolutionary development. ${ }^{17}$ Even some prominent experts on civil law emphasize harmony in the transformation of private law, which is more likely to be brought about by the long-term competition of ideals and concepts, and decades of evolving internal social conviction than by direct action. Much has already been written on this subject.

As far as the European Court of Human Rights is concerned, there is no doubt that the generally shared values are the central theme in its case law and positively influence the development of family law, its interpretation, and application. It is not without interest that in foreign literature, national constitutional courts are often referred to as the driving force offamily law. ${ }^{18}$ The influence of the case law of the European Court of Human Rights on family law, as reflected by national constitutional courts, is thus gradual but unquestionable. Much is changing, rather spontaneously, which supports the phenomenon known as the de facto convergence of systems of family law in Europe, or their Europeanization. ${ }^{19}$ This is especially due to Article 8 of the Convention for the Protection of Human Rights and Fundamental Freedoms, guaranteeing everyone the right to respect for private and family life, but also to Article 14, enshrining the requirement of non-discrimination, and, last but not least, to Article 6, providing for the right to a fair trial. The case-law of the European Court of Human Rights thus forms, in essence, a universal basis, or at least a general values guideline.

It should be pointed out that the Principles of European Family Law developed by the European Commission on European Family Law are also based on a 'common core'. They may therefore appear to be a compromise. However, in the light of developments, some of them call for 'better law'.$^{20}$ In general, they can be characterized by generality, simplicity, and timelessness.

The question is whether actions of the European Commission on Family Law should be seen as an overly ambitious project or as a rational inspiration for national legislators. There is no doubt that they are gradually gaining complexity and have already been considered to a greater or lesser extent in the legislative process in several European countries, even

16 | For more details see Stalford, 2002, p. 410; Caracciolo Di Torella, Masselot, 2004, p. 32; Antokolskaia, 2007.

17 | See Douglas, Lowe, 2009.

18 | For instance, see Dethloff, Kroll, 2006, p. $229 \mathrm{ff}$.

19 | In details see Müller-Freienfels, 1968 -1969, pp. 175-218.

20 | Regarding the working methods, see Boele-Woelki, 2005, p. $15 \mathrm{ff}$. 
if they are by no means binding. This has brought the results of academic work closer to practice and has helped to bring about a de facto convergence of systems of family law in Europe. The Commission's objectives of achieving a genuine European identity and modernization of the legal systems are thus gradually being achieved.

\section{Toward the recodification of Czech family law and its sources of inspiration}

The new Czech family law is the result of long-term legislative work, ${ }^{21}$ in which completely contradictory opinions, from quite liberal to very conservative ones, ${ }^{22},{ }^{23}$ often met. In addition, tradition versus innovation were in a relevant tension. ${ }^{24}$ In the following section, however, particular reference will be made to the extent to which the Principles

of European Family Law produced by the European Commission on European Family Law were taken into account at the time of its adoption.

It should be added that family law was incorporated into 'Book Two' of the Civil Code ${ }^{25}$ within the recodification of the basic source of Czech private law. The legal regulation of registered partnerships remained established in a separate act. ${ }^{26}$ Like any great work, the new Civil Code was supplemented by extensive accompanying legislation. As far as family law is concerned, most family law cases are now judged in court proceedings not according to the general procedural norm, the Code of Civil Procedure, but according to the new Act on Special Civil Proceedings. ${ }^{27}$

However, the development of family law legislation in the Czech Republic is not complete, especially with regard to the position of same-sex couples, which is developing under the influence of case law in the European Court of Human Rights. Many foreign legal systems have approached the issue in a gender-neutral manner. ${ }^{28}$ However, the Commission on European Family Law has not given attention to this matter thus far. As already mentioned in the introduction, in the Czech Republic, this issue is now very topical, as the Parliament of the Czech Republic is currently debating, among other things, a proposal to establish 'marriage for everyone'.

As it is generally accepted that family life can take many forms, many codes in Europe provide protection for non-marital family life. This is to be welcomed, as we cannot turn a blind eye to the fact that almost half of children in the Czech Republic are born out of wedlock. ${ }^{29}$ However, this issue is not pressing for Czech society and the Civil Code does not associate excessive consequences with unmarried cohabitation. The relative novelty

21 | Regarding many such attempts, see Haderka, 1996, Haderka, 2000.

22 | See Eliáš, Zuklínová, 2001.

23 | For more see Eliáš, Zuklínová, 2005.

24 | In details Králíčková, 2014.

25 | Act No 89/2012 Sb., Civil Code, as amended.

26 | Act No 115/2006 Sb., on Registered Partnership, as amended.

27 | Act No 292/2013 Sb., on Specific Civil Law Proceedings, as amended.

28 | See Sörgjerd, 2012.

29 | For more see https://www.czso.cz/ (retrieved on 21 June 2021). 
of the Commission on European Family Law, which is discussed below, may be all the more inspiring for Czech legislators.

\section{The Principles of European Family Law regarding Divorce and Maintenance between Former Spouses (Principles I) ${ }^{30}$}

During the second half of the twentieth century, a new view on the (in)dissolution of marriage emerged in several European countries. ${ }^{31}$ The development in many places went from the principle of fault, through so-called divorce based on irretrievable breakdown, to consensual divorce, or the administrative dissolution of marriage. Divorce is thus nowadays generally seen as a legitimate solution to the crisis of marital cohabitation.

The contribution of Principles I can be seen especially in the fact that they fully respect the autonomy of the human will, do not obscure the essence of the matter, and do not create complex or incomprehensible concepts that do not benefit anyone.

Principles I distinguish two types of divorce. The key factor is whether or not the spouses are able to agree on the dissolution of their marriage by divorce, whether they are also parents of a minor child, and whether they have concluded an agreement on the division of their property.

In the first place, divorce by mutual consent is mentioned (Principles 1:4 et seq.), the prerequisites of which do not include the need to observe any minimum duration of marriage or de facto separation, nor the need to conclude a property agreement on the postdivorce settlement. However, this option reasonably provides for a period of reflection in cases in which the spouses are also parents of a minor child under 16 or have failed to conclude a property settlement agreement, in part or in full.

In the second place, divorce without the consent of one of the spouses is provided for (Principles 1:8 et seq.), being based-in Czech terminology-on the so-called irretrievable breakdown of marriage, but the court is not obliged to examine it or its causes, as it is inferred from the de facto separation of the spouses for a period of one year. This approach of the drafters of Principles I fully reflects the development of European society.

Principles I also provide for the so-called hardness clause in favor of the spouse seeking the divorce. In some cases, there is no need for de facto separation of the spouses for one year (Principle 1:9). This may be used if the marital cohabitation is disturbed by domestic violence or mental disorder, for example.

Regarding the maintenance duty of the divorced spouses, this is established as an extraordinary measure, the prerequisite of which is dependence on maintenance or the inability to meet one's own needs. Principles I do not include the so-called sanction maintenance, a relative innovation of the Czech legal system established in $1998,{ }^{32}$ the essence of which is the right to the same standard of living for a maximum of three years under relatively strict conditions.

Unfortunately, within the recodification of the Czech Civil Code, Principles I were not adopted or even taken into account and the Czech legal regulation of divorce is currently

30 | Boele-Woelki, Ferrand, González-Beilfuss, Jänterä-Jareborg, Lowe, Martiny, Pintens, 2004.

31 | For more details see Verschraegen, 2004.

32 | See Králíčková, 2008. 
the subject of much discussion. The legal regulation of divorce has been based on the irretrievable breakdown of marriage since $1963 .^{33}$ The new Civil Code sets forth that marriage may be dissolved if the joint life of the spouses is deeply, permanently, and irretrievably broken down and its recovery cannot be expected. The court deciding the divorce shall examine the fact of breakdown of the marriage and the reasons leading to it. This variant of divorce is called contested divorce. However, if the spouses have agreed about the divorce, the court does not examine reasons for the breakdown if it comes to the conclusion that the identical statements of the spouses about the breakdown of their marriage and about their intent to achieve divorce are true. This is called uncontested divorce. ${ }^{34}$ The following requirements must be met:

a) on the day of the commencement of the divorce proceedings, the marriage has lasted for one year at least and the spouses have not lived together for more than six months,

b) the spouses, who are parents of a minor child without full legal capacity, have agreed on arrangements for the child for the period after the divorce and the court has approved their agreement,

c) the spouses have agreed on the arrangement of their property, their housing and, if the case may be, the maintenance for the period after the divorce; the property contract must be in writing with officially authenticated signatures.

Like the previous law, which was amended in 1998, the new law establishes the socalled clause against harshness.

If the spouses have a minor child, the court will not grant a divorce until the special court dealing with the agenda on minors decides on the custody of the child for the period after the divorce. The court dealing with the custody of the minor child may decide on or approve the agreement of the spouses in the matter of entrusting the minor child into the individual (sole) custody of one parent, alternating (serial) custody, or joint custody of the parents. It is necessary to emphasize that both parents of the child are principally holders of rights and duties resulting from parental responsibility (see below) and the decision on after-divorce custody only determines who the minor child will live in the common household with (besides the maintenance duty toward the child and visitation rights).

It is necessary to mention that a pending draft ${ }^{35}$ in the Parliament of the Czech Republic aims to make the situation of divorcing parents of a minor child equal or at least similar to that of non-married parents of a minor child who separated without any interventions by the state, thanks to the mutual non-formal agreement. The pending draft is based on the opinion that the parents of a minor child know their child very well and seek to follow the best interest of the child even when separating. Should the draft be passed, the divorce of a husband and a wife-who can agree on divorce and on property and dwelling consequences of divorce and on post-divorce arrangement regarding their minor children-would be amicable, smooth, and quick. The divorcing couple will have to submit to the judge only the common motion for granting the divorce, the property and dwelling contract, and the agreement on minor child regarding custody, maintenance and, if the case may be, visitation rights. The judge dealing with the divorce will not have to

$33 \mid$ Op. cit.

34 | The new legal regulation does not know the so-called divorce on the basis of agreement, i.e. consensual divorce or divorce by mutual consent.

35 | Parliament of the Czech Republic, Chamber of Deputies, Parliamentary term No. VIII., Draft No. 899. 
approve the property contract or the agreement on custody and maintenance toward the minor children. However, without fulfilling all the legal conditions, the marriage cannot be terminated.

\section{The Principles of European Family Law on Parental Responsibilities (Principles II) ${ }^{36}$}

After the Second World War, national legislation in many European countries sought to redefine the rights of children and to eliminate discrimination against children born out of wedlock. The adoption of a number of declarations and, later, human rights conventions, in particular the universal Convention on the Rights of the Child, the European Convention on the Exercise of the Rights of the Child and the European Convention on Contact with Children, ${ }^{37}$ undoubtedly contributed to this approach. The Czech Republic, and the former Czechoslovakia, initiated reforms that resulted in children being regarded not as passive objects of the will of their parents or a paternalistic or totalitarian State, but as fully-fledged and active entities. ${ }^{38}$ This entailed many things, including a change in terminology or the abandonment of some obsolete terms such as 'illegitimate child', and a move away from the institution of 'paternal power' or 'parental rights and obligations', to the concept of 'parental responsibility', which had already been established in the 1990s in connection with international conventions and essentially adopted by the new Civil Code, but was adopted as a new concept in connection with Principles II.

From this perspective, the Civil Code appears fundamentally in line with European family law standards, although the substantive intention and many working versions of the draft of the new Civil Code were based on a different concept.

First, it should be stated that Principles II are not based on a mere trichotomy like the earlier Czech concept of parental responsibility, but they divide the rights and obligations arising from parental responsibility into five partial rights and obligations. These include, in addition to the traditional ones, (a) care and upbringing of the child, (b) management of the child's property and (c) legal representation of the child, (d) the right to maintain personal relationships and, in particular, and (e) the right to determination of residence of the child (Principle 3:1). This approach seems to be more appropriate, as it considers humanitarian issues, the reality of free borders and migration, and thus the negative consequences, or the illegal relocation of children, or their international abduction.

As a contribution of Principles II to the discussion of the draft, the new Civil Code should be considered primarily a broader conception of the content of parental responsibility, and the distinction between the 'holding' of parental responsibility and the 'exercising' of the individual rights and obligations as belonging to this conception. It is also worth highlighting that the position of parents of minor children is being strengthened in favor of parents who are incapacitated, or minors, particularly in relation to personal care or contact with the child. It should also be stressed that the exercise of rights and obligations

36 | For more see Boele-Woelki, Ferrand, González-Beilfuss, Jänterä-Jareborg, Lowe, Martiny, Pintens, 2007.

37 | See Van Bueren, 2007.

38 | For details see Hrušáková, 2002, and Hrušáková, Westphalová, 2011. 
arising from parental responsibility after divorce or in the event of separation of parents have been thoroughly regulated and that explicit rules have been established for parents and prospective adoptive parents that will undoubtedly prevent conflicts. With regard to the limitation and removal of parental responsibility as a 'sanction' for parents who abuse their rights and obligations, it is worth mentioning in particular the provisions according to which the court must deal with the parent's contact with the child or deprive the parents of the right to consent to the adoption. ${ }^{39}$

\section{The Principles of European Family Law regarding Property Relations between Spouses (Principles III) ${ }^{40}$}

It is generally acknowledged that the subject matter of matrimonial property law varies across European national systems. It particularly differs between countries that use continental law and those that use Anglo-Saxon law. There are thus many property systems. Individual civil codes, which have historical roots, have systems ranging from 'separate property' to 'community property', from 'property acquired only through marriage', with numerous statutory exceptions, to 'property of the whole community'. However, after the Second World War, a common trend among many legislators can be traced, regarding the desire to protect the weaker party and to strengthen family solidarity in the framework of amendments. This not only concerns property systems as such, but in particular the establishment of a special arrangement for the goods forming the usual equipment of the family household and the so-called non-disposability of the family home. The Commission on European Family Law therefore respects the value basis of matrimonial law, or matrimonial property law, which is common to family law systems in Europe.

It can be said that although Principles III were published after the adoption of the new Czech Civil Code, the legal regulation of matrimonial property law and housing included in its 'Book Two' is consistent in value with both the concept and the individual rules.

The Commission on European Family Law was primarily concerned with the question of whether tradition should be respected, or whether the statutory property system should be regulated first and only then the contractual system, or vice versa. ${ }^{41}$ We believe that the latter approach gives the spouses a greater degree of autonomy. In the new Civil Code, the matter is dealt with in a traditional way, or in favor of the statutory matrimonial property system regulated in the first place, even though the historical arrangements here were based on the marriage contract (see the ABGB in particular). ${ }^{42}$

As far as the particulars of Principles III are concerned, the general rights and obligations of spouses are specified (Principles 4:1 to 4:9). They protect the equality of spouses and the autonomy of the will to contract both before marriage and at any time during marriage. They also regulate the obligation to contribute to the needs of the family, the need for the consent of both spouses when disposing of their own or rented dwelling and

39 | For more see Králíčková, Hrušáková, Westphalová, 2020.

40 | Boele-Woelki, Ferrand, González-Beilfuss, Jänterä-Jareborg, Lowe, Martiny, Pintens, 2013.

41 | For more details see Boele-Woelki, Jänterä-Jareborg, 2011, p. 47 ff., mainly pp. 57-58.

42 | See Psutka, 2015. 
the usual equipment of the family household. They also lay down rules on mutual representation in legal matters concerning the spouses, the obligation to inform the spouse of exclusive assets and liabilities, and of important administrative actions when they could endanger the other spouse.

It should be stressed that the protection of the family home and its usual or basic equipment (household goods) (Principle 4:5, 4:6) has long been a feature of many European private law codes. The new Civil Code also takes these values into account, and can be considered a breakthrough in this area. A related issue is the possibility for the weaker party to claim the invalidity of both unfavorable terms of disposal of movable property serving the needs of the family and the hindrance or impossibility of living in the family home.

Principles III allow for both a community property and a separate property system. These systems are equivalent, while fully reflecting the autonomy of the will of the spouses or future spouses. The marital property arrangement can be modified or changed during the marriage. The agreement may cover all or only certain assets, for example movable or immovable property. It may also exclude certain types of property from the matrimonial property arrangement. In terms of form, the contract must be drawn up by a notary (or other legal professional with a comparable function, e.g. in the Nordic countries, see Principle 4:13).

Principles III emphasize the need for publicity. A matrimonial property contract is effective against a third party if an entry is made in a public register or if the substance of the contract is otherwise known to the third party (Principle 4:14). The new Czech legislation is fully in line with Principles III in this respect, which puts it among the countries where the publicity of matrimonial property contracts has been established for years and constitutes a traditional pillar of third-party rights protection. It is thus undoubtedly the 'common core' of European matrimonial property law. ${ }^{43}$

As an element of the 'better law', Principles III establish the so-called hardness clause, exceptional hardship (Principle 4:15). It provides that in the event of a change in the terms and conditions from those under which the contract was made, the competent authority may exclude the effectiveness of the contract or modify the contract. The Czech Civil Code does not regulate this matter.

\section{The Principles of European Family Law regarding Property, Maintenance, and Succession Rights of Couples in de facto Unions (Principles IV) ${ }^{44}$}

As mentioned above, Principles IV concerning unmarried cohabitation were only developed after the adoption of the new Czech Civil Code. They provide considerable protection for de facto unions, given that even the Preamble points out that the number of informal unions is increasing in society. The aim of Principles IV is to balance, on the one hand, the autonomy of will and freedom of contract of the contracting parties and, on the other hand, the need to protect the weaker party, but also to ensure the welfare of the

43 | For details see Králíčková, Kornel, Zavadilová, 2019.

44 | See Boele-Woelki, Ferrand, González-Beilfuss, Jänterä-Jareborg, Lowe, Martiny, Todorova, 2019. 
family of couples in de facto unions. It should be added that Principles IV do not distinguish between same-sex and different-sex unions. The introductory lines suggest that de facto unions consist of two persons living together and forming a permanent relationship of at least five years or having a child in common (Principle 5:1). Furthermore, the equality of rights and obligations (Principle 5:4) and the possibility of concluding agreements and their scrutiny by the competent authority are emphasized (Principles 5:8 and 5:9). Particular attention is paid to the contribution to the joint costs of the household and the protection of the family home and household goods (Principle 5:6). Principles IV provide for a presumption of joint ownership (Principle 5.12) and special rules for separation (Principles 5:15 et seq.) and death (Principles 5:22). This not only applies to property as such and maintenance, but also to the family home and household goods.

Regarding Czech Family Law, due to the limited concept of family as regulated in the Civil Code, there are no articles that would establish mutual right and duties between cohabitees. Unfortunately, property contracts between the cohabitees are rare, which can cause problems for the so-called weaker party upon the dissolution of the de facto relationship. However, as there is no discrimination of parental rights regarding children born out of wedlock, the rights and duties of the parents of any child are equal. It should be mentioned that if an unmarried man and an unmarried woman 'have a child together', they are both principally holders of parental responsibility by operation of law (for details, see above) without being discriminated against in comparison with married parents of a minor child. The law traditionally protects the property claims of the unmarried mother of the child. The Civil Code regulates the 'maintenance and support, and provision for the payment of certain costs for an unmarried mother'. ${ }^{45}$ Regarding rights of a surviving cohabitee, his or her situation is in practice very weak as there is seldom a will. The surviving cohabitee must prove many details from common life during the proceedings, unlike the rules set out in Principles IV.

Regarding the designed law, it is worth considering whether and how the Civil Code should be amended in this area. Persons of different sexes can marry and enjoy the legal protection afforded to spouses by the Civil Code, both in the personal and property matters, even in the event of the dissolution or annulment of the marriage by divorce. Same-sex couples can benefit from registered partnership, which, although it does not come with a very wide set of rights and obligations, is a status relationship that is relevant to the entire legal order. Should the legislator respect the autonomy of the will of persons who 'refuse' the marital or 'official' partnership status, or should the law maker associate substantial legal consequences with the de facto unmarried cohabitation? There are rarely property contracts, inheritance contracts, or wills between unmarried persons, which is to the detriment of the weaker parties, in particular those who, following the de facto separation or death of the 'main breadwinner', care for minor children together and therefore do not have sufficient independent sources of livelihood and the possibility of living on their own legal basis. 


\section{Conclusion}

In conclusion, we can say that family law has its limits and cannot be changed on a daily basis. Not only in the Czech Republic, but in many European countries, family law has been undergoing gradual changes in response to the convergence of lifestyles and changes in the family and society in general. For legislators in many European countries, the need to find common methods is coming to the fore due to globalization. ${ }^{46}$ People exercise their right to family life according to their wishes, ideas, and opportunities. Many get married or enter into registered partnerships with foreigners and in foreign countries, move, have children, get divorced, and die. Although there has been a spontaneous convergence of systems of family law in Europe, especially due to the values set out long ago by international conventions, the influence of the Council of Europe and the case-law of the European Court of Human Rights, it is still quite difficult to describe the European standard in all its detail. However, the unquestionable value is and must be respect for the human being, including the minor child, for their human rights and freedoms, autonomy of will, and protection of the weaker party.

In principle, the Czech Republic does not fall outside of European trends. ${ }^{47}$ In general, the harmonization and unification tendencies in family law are already slowly influencing the development of family law in the Czech Republic. A certain reticence, even indifference, can be seen with regard to the Principles of European Family Law drawn up by the Commission on European Family Law, especially with regard to the dissolution of marriage (Principles I). However, these are not binding. Nevertheless, as mentioned above, this area is currently undergoing substantial changes. Regarding parental responsibility, or its conception and value, it can be noted that the most important aspects have been considered in the recodification process (Principles II). A similar conclusion can be drawn about the values, especially the protection of the weaker party and family solidarity, in relation to the new Czech matrimonial property law (Principles III). It is unclear whether the relatively recently adopted concept of unmarried cohabitation will be a challenge for Czech legislators (Principles IV). One can agree with the view that the new private law code should, in principle, cover all private law matters, including family law, as is customary in countries with comparable legal environments. ${ }^{48}$ However, the autonomy of will of the free person must be respected. In private law, the balance of values, harmony, the protection of the weaker party and the interests of the family as a whole, whatever form it may take, must always be sought.

46 | For more details see Scherpe, 2016.

47 | See Králíčková, 2009, and Králíčková, 2014.

48 | Towards theoretical issues see Zuklínová, 2003, pp. 141 ff. 


\section{Bibliography}

Antokolskaia, M. (2003) 'The Harmonisation of Family law: Old and new Dilemmas', European Review of Private Law, 11(1), pp. 28-49.

Antokolskaia, M. (ed.) (2007) Convergence and Divergence of Family Law in Europe. Cambridge: Intersentia.

Bělovský, P. (2009) 'Rodinné právo (Family Law)' in Bobek, M., Molek, P., Šimíček, V. (eds.) Komunistické právo v Československu. Kapitoly z dějin bezpráví (Communist Law in Czechoslovakia. Chapters in History of Injustice). Brno: Masarykova univerzita.

Boele-Woelki, K. (2005) 'The Working Method of the Commission on European Family Law' in Boele-Woelki, K. (ed.) Common Core and Better Law in European Family Law. Cambridge: Intersentia.

Boele-Woelki, K., Ferrand, F., González-Beilfuss, C., Jänterä-Jareborg, M., Lowe, N., Martiny, D., Pintens, W. (2007) Principles of European Family Law regarding Parental Responsibilities. Cambridge: Intersentia.

Boele-Woelki, K., Ferrand, F., González-Beilfuss, C., Jänterä-Jareborg, M., Lowe, N., Martiny, D., Pintens, W. (2004) Principles of European Family Law regarding Divorce and Maintenance Between Former Spouses. Cambridge: Intersentia.

Boele-Woelki, K., Ferrand, F., González-Beilfuss, C., Jänterä-Jareborg, M., Lowe, N., Martiny, D., Pintens, W. (2013) Principles of European Family Law regarding Property Relations Between Spouses. Cambridge: Intersentia.

Boele-Woelki, K., Ferrand, F., González-Beilfuss, C., Jänterä-Jareborg, M., Lowe, N., Martiny, D., Todorova, V. (2019) Principles of European Family Law regarding the Property, Maintenance and Succession Rights and Duties of Couples in de facto Unions. Cambridge: Intersentia.

Boele-Woelki, K., Jänterä-Jareborg, M. (2011) 'Initial Results of the Work of the CEFL in the Field of Property Relationsbetween Spouses' in Boele-Woelki, K., Miles, J., Scherpe, J. (eds). The Future of Family Property in Europe. Cambridge: Intersentia.

I Brems, E. (ed.) (2008) Conflicts Betwen Fundamental Rights. Cambridge: Intersentia.

Brüggemeier, G., Colombi Ciacchi, A., Comandé, G. (eds.) (2010) Fundamental Rights and Private Law in the European Union. Volume I, II. Cambridge: Cambridge University Press.

Caracciolo Di Torella, E., Masselot, A. (2004) 'Under Construction: EU Family Law', European Law Review, Vol. 24, pp. 32-51.

Dethloff, N., Kroll, K. (2006) ‘The Constitutional Court as Driver of Reforms in German Family Law. Part IV, Premarital and Marital Settlement Agreements. A Constitutional requirement of judical control' in Bainham A. (ed.) The International Survey of Family Law. 2006 Edition, Jordan Publishing Limited.

Douglas, G., Lowe, N. (2009) The Continuing Evolution of Family Law. Bristol: Jordan Publishing Limited. 
Eliáš, K., Zuklínová, M. (2001) Principy a východiska nového kodexu soukromého práva (Principles and Starting Points of the New Code of Private Law). Praha: Linde.

Eliáš, M., Zuklínová, M. (2005) Návrh občanského zákoníku (Draft for the Civil Code). Praha: Ministry of Justice.

Haderka, J. F. (1996) ‘The Czech Republic - New Problems and Old Worries’ in Bainham, A. (ed.) The International Survey of Family Law 1996 Edition. The Hague-BostonLondon: Martinus Nijhoff Publ.

Haderka, J. F. (2000) 'A Half-Hearted Family Law Reform of 1998' in Bainham, A. (ed.) The International Survey of Family Law 2000 Edition. Bristol: Jordan Publishing.

Hrušáková, M. (2002) 'Czech Republic' in Blainpain, R. (ed.) The International Encyclopaedia of Laws. The Hague/London/New York: Kluwer Law International.

Hrušáková, M., Westphalová, L. (2011) Czech Republic. 2nd ed. In Blainpain, R. (gen. ed.) The International Encyclopaedia of Laws. The Hague/London/New York: Kluwer Law International.

Králíčková, Z. (2008) 'Development in Marriage and Marital Law in the Czech Republic (After the Communist take-over, Collapse of Communism and Accessing the European Union)' in Wardle, L.D., Loveless, A. S. (eds.) Marriage and Quasi-Marital Relationships in Central and Eastern Europe. Provo, BYU Academic Publishing.

Králíčková, Z. (2009) ‘Czech Family Law: The Right Time for Re-Codification’ in Atkin, B. (ed.) The International Survey of Family Law 2009 Edition. Bristol: Jordan Publishing.

Králíčková, Z. (2009) 'Legal Protection of Unmarried and Divorced Mothers in the Czech Republic' in Verschraegen, B. (ed.) Family Finances. Vienna: Jan Sramek Verlag.

Králíčková, Z. (2010) Lidskoprávní dimenze českého rodinného práva (Human Rights Dimension of Czech Family Law). Brno: Masarykova univerzita.

Králíčková, Z. (2012) 'České rodinné právo ve světle evropských harmonizačních tendency (Czech Family Law in the Light of European Harmonisation Tendency)', Právník, 151(11), pp. 1161-1184.

Králíčková, Z. (2013) ‘Rodinné právo v novém občanském zákoníku (Family Law in the New Civil Code)', Právní rozhledy, 21(23-24), pp. 801-813.

Králíčková, Z. (2014) 'New Family Law in the Czech Republic: Back to Traditions and Towards Modern Trends' in Atkin, B. (ed.) The International Survey of Family Law 2014 Edition. Bristol: Jordan Publishing.

Králíčková, Z. (2021) 'On the Family and Family Law in the Czech Republic' in Barzó, T., Lenkovics, B. (eds.) Family Protection from a Legal Perspective. Analysis on Certain Central European Countries. Budapest-Miskolc: Ferenc Mádl Institute of Comparative Law-Central European Academic Publishing, pp. 77-109.

Králíčková, Z., Hrušáková, M., Westphalová L. et al. (2020) Občanský zákoník II. Rodinné právo (Section 655-975). 2. vyd. Komentár̆. (Civil Code II. Family Law (Sections 655-975). 2nd ed. Commentary). Praha: C. H. Beck. 
Králíčková, Z., Kornel, M., Zavadilová, L. (2019) Czechia. In Ruggeri, L., Kunda, I., Winkler, S. (eds.) Family Property and Succession in EU Member States National Reports on the Collected Data. Croatia: Rijeka, p.122-159, available at https://www.euro-family. eu/documenti/news/psefs_e_book_compressed.pdf (cit. 27. 3. 2021).

Martiny, D. (1995) 'Europäisches Familienrecht - Utopie oder Notwendigkeit?' Rabels Zeitschrift für ausländisches und internationales Privatrecht, 59(3-4), pp. 419-453.

Martiny, D. (1998) 'Is Unification of Family Law Feasible or Even Desirable?' in Hartkamp, A. et al. (eds.) Towards a European Civil Code. 2nd ed. The Hague/London/ Boston: Kluwer Law International.

McGlynn, C. (2006) Families and European Union. Law, Politics and Pluralism. Cambridge: Cambridge University Press.

Meulders-Klein, M.-T. (2003) ‘Towards a European Civil Code on Family Law? Ends and Means' in Boele-Woelki, K. (ed.) Perspectives for the Unification and Harmonisation of Family Law in Europe. Cambridge: Intersentia.

Mladenović, M., Janjić-Komar, M., Jessel-Holst, C. (1998) The Family in Post-Socialist Countries. The International Encyclopedia of Comparative Law, Vol. IV, Chapt. 10, Tübingen.

Müller-Freienfels, W. (1968-1969) 'The Unification of Family Law', The American Journal of Comparative Law, 16(1/2), pp. 175-218.

Pintens, W. (2003) 'Europeanisation of Family Law' in Boele-Woelki, K. (ed.) Perspectives for the Unification and Harmonisation of Family Law in Europe. Cambridge: Intersentia.

Psutka, J. (2015) Společné jmění manželů (Community Property between the Spouses). Praha: C. H. Beck.

Scherpe, J. M. (2016) The Present and Future of European Family Law. CheltenhamNorthampton: Edward Elgar.

Sörgjerd, C. (2012) Reconstructing Marriage. The Legal Status of Relationships in Changing Society. Cambridge: Intersentia.

Stalford, H. (2002) 'Concepts of Family Law under EU Law - Lessons from the ECHR', International Journal of Law, Policy and the Family, 16(3), pp. 410-434; https://doi. org/10.1093/lawfam/16.3.410.

I Van Bueren, G. (2007) Children Rights in Europe. Strasbourg: Council of Europe.

Verschraegen, B. (2004) Divorce. The International Encyclopedia of Comparative Law, Vol. IV, Chapt. 5. Tübingen.

Zuklínová, M. (2003) ‘Budoucí občanský zákoník a rodinné právo (Future Civil Code and Family Law)' in Otázky rekodifikace soukromého práva (Issues of Recodification of Private Law). Acta Universitatis Carolinae, Iuridica, No. 1/2. 